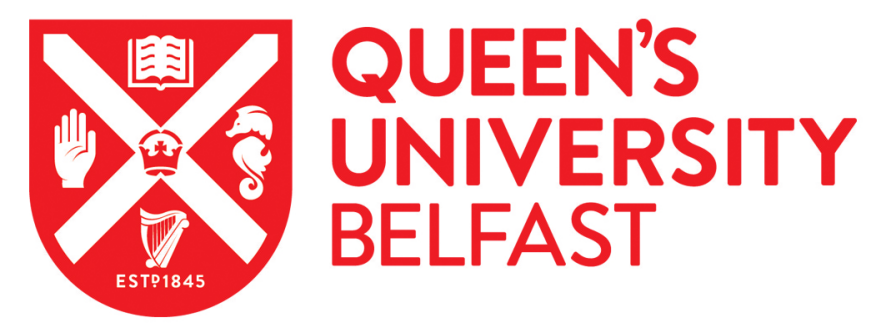

\title{
The Multidirectional Memory of Charlie Hebdo
}

Hollis-Touré, I. (2016). The Multidirectional Memory of Charlie Hebdo. French Cultural Studies, 27(3), 293-302. https://doi.org/10.1177/0957155816648102

Published in:

French Cultural Studies

Document Version:

Peer reviewed version

Queen's University Belfast - Research Portal:

Link to publication record in Queen's University Belfast Research Portal

Publisher rights

(C) 2016 The Authors.

\section{General rights}

Copyright for the publications made accessible via the Queen's University Belfast Research Portal is retained by the author(s) and / or other copyright owners and it is a condition of accessing these publications that users recognise and abide by the legal requirements associated with these rights.

Take down policy

The Research Portal is Queen's institutional repository that provides access to Queen's research output. Every effort has been made to ensure that content in the Research Portal does not infringe any person's rights, or applicable UK laws. If you discover content in the Research Portal that you believe breaches copyright or violates any law, please contact openaccess@qub.ac.uk. 


\title{
The Multidirectional Memory of Charlie Hebdo:
}

\section{Isabel Hollis}

\section{Queen's University Belfast}

\begin{abstract}
This article will discuss notions and concepts of remembering in the aftermath of the Charlie Hebdo attacks. Much has been written about the immediate response to the attacks, both commending the collective spirit of unity that defined the 'marche républicaine' of 11 January 2015, and criticising the alleged hypocrisy and cynicism of, most notably, the political figures that took to the streets that day, hand in hand. I will consider a selection of the memory practices that have emerged since then, notably at the anniversary of the event. This demonstration of memory provides key insights into the form and manner of remembering within a particular cultural group, but also reflects how the present moment is integral to our understanding of memory. The purpose of this article is to consider how official and non-official remembering of Charlie Hebdo can intertwine as well as pull in separate directions. A focus on the politics, the language, the aesthetics and the geography of commemorative activities in this article will enable an appreciation of the multidirectional character of remembering Charlie Hebdo.
\end{abstract}

Isabel Hollis is a Research Fellow at Queen’s University Belfast. Her research focuses on immigration from North Africa to France and it’s representation across different forms of media. Her recent monograph, From North Africa to France (IGRS books, 2015) compared literature and film to emerge from the North African migration flow to France. She currently works on museums and memorials in contemporary France. 
i.hollis@qub.ac.uk

\section{Remembering in the present}

After 9/11, French theorist Jean Baudrillard wrote that 'Nous avons même affaire, avec les attentats de New York et du World Trade Center, à l’événement absolu, la “mère” des évenements’ (2002: 9). It is fitting, then, that perhaps the most emblematic, in the western hemisphere at least, of memorials to victims of the crimes we describe as 'terrorism' are the 9/11 memorial pools and the accompanying museum. Opened on 12 September 2011, the design is a reflection on absence, with two man-made waterfalls collapsing into the ground where the towers once stood, and victims' names inscribed on plaques attached to the pools' walls. A focal point of the memorial and museum site is the Survivor Tree, a callery pear tree that was growing on the site of the attack, and survived despite severe damage. As the memorial website informs us, 'New, smooth limbs extended from the gnarled stumps, creating a visible demarcation between the tree's past and present. Today the tree stands as a living reminder of resilience, survival and rebirth.’

The affirmation of life in the memory of death is a commemorative trope that attempts to reassure and rehabilitate the affected population. The resilience of nature in the face of manmade disasters acts as inspiration for many a commemorative initiative. The coincidence of the Charlie Hebdo terrorist attacks occurring in Paris in the same year as it hosted the COP 21 led to the launch on 19 March 2015 of 'l'arbre de la Fraternité et du vivre-ensemble' (France Diplomatie, 2015), an initiative led by Michel Taube, head of the collective Ensemble citoyens. He began the project by planting an olive tree in the Grand Palais. His gesture was not only 
symbolic of peace, but also deliberately recollective of both the olive branch held by Marianne in the statue at Place de la République, and of the 'arbre de la liberté' - the trend of planting poplar trees during the French Revolution and its aftermath, an act that was accomplished with great ceremony and celebration. Many of these poplar trees are still standing today, and have been sites of public gathering and reaffirmation of core values in response to the confusion, fear and anger provoked by 'terrorist’ attacks last year (Tritah, 2015). This circular framework in which trees of fraternity are planted to commemorate terrorism, and trees of liberty are revisited to display fraternity in the aftermath of terrorism, each referencing one another, indicates the 'layered structure and unpredictable energy of collective memory', which this article will explore in relation to the Charlie Hebdo attacks (Rothberg et al., 2010: 2).

Public commemorations and memorials, whether the product of popular or government initiative, are ostensibly produced in order to facilitate the process of 'moving on'. This affirmation of life was present in the brandishing of pens and the drawing of cartoons as a response to the Charlie Hebdo attacks and, later that same year, it was the ethos behind the 'faites la fête' movement that followed 13 November 2015 in Paris. The manner in which the crimes that constitute terrorism are commemorated are representative not only of the nature of the attack, then, but also of the present moment in which they are being remembered. Thus the 9/11 Memorial Museum includes a section dedicated to the contemporary global significance of the attacks, and the museum's collection is in constant evolution, with calls on the website for materials such as 'photographs, videotapes, voice messages, recovered property, clothing and other personal effects, workplace memorabilia [...]'. Similarly, the public memorial to Charlie Hebdo situated at the Léopold Morice statue of Marianne, Place de la République, still bears 
multiple different representations of the 'Je suis Charlie' slogan that emerged from the attack, yet has also come to incorporate the more recent messages to the victims of 13 November.

Members of the public continue to take it upon themselves to maintain the memorial, removing dead flowers, tidying up and rearranging the various messages displayed there. They have formed a collective, known as '17, plus jamais', referring to the 17 people killed in January 2015. Their leader arranges public gatherings to tidy the memorial and preserve as many messages as possible, 'pour l'histoire', she states (Sabrina, France Inter, 2015). As Andreas Huyssen has shown, this cathartic prerogative can be a double-edged sword: 'today we rather think of memory as a mode of re-presentation and as belonging ever more to the present. After all, the act of remembering is always in and of the present, while its referent is of the past and thus absent. Inevitably, every act of remembering carries with it a dimension of betrayal, forgetting, and absence' (Huyssen, 2003: 3-4). And so despite the surge of solidarity and yearning to remember together that pushed millions into the streets after the attacks, politics were far from absent from the proposed memory act in France of a republican march: President François Hollande appealed to Nicolas Sarkozy to join the march, and the leader of the opposition took a full day to confirm his attendance (Vitkine, 2016). As Vitkine’s documentary shows, political strategy works to influence forms of commemoration as they emerge.

Indeed, multiple voices contribute to the memory narrative, whether political, or those of victims and their families, activist groups or those who work in the memory 'business' (museum workers, for example). The very act of selecting the form and manner of the commemorative act leads governments, municipalities, political groups and societies amongst others to hone and refine the narrative that emerges from the event being remembered. When a memory narrative is formed in response to 'terrorist' crimes, two different prerogatives are at play: on the one hand, 
the commemoration of the victims, on the other hand the reminder of the event's horror and, implicitly, the need for continued vigilance - a need which introduces the political dimension. A commemorative narrative is frequently reflective not of the event itself, then, but of the hierarchical power relations of the competing groups remembering it.

\section{Charlie Hebdo: a multidirectional memory}

The constantly evolving manner in which the Charlie Hebdo attacks are remembered has been typified by a spatial evolution. This is because, since the events of January 2015, multiple other attacks in different parts of the world have led to parallels with January in Paris. The attacks on the World Trade Centres in 2001 and on the Charlie Hebdo staff in 2015 had in common the destruction of symbolic values held dear in much of the western world, and that each was seen as representing: in the former case, global capitalism at its most ostentatious; in the latter case, freedom of expression in the media, especially when that was considered to constitute offence and blasphemy. Forms of destruction in other geopolitical regions have attacked symbolism from a different angle: the destruction of historic and religious sites in places such as Palmyra has attempted to annihilate physical manifestations of cultural memory across the Middle East.

Such attacks do not only impact upon the nation-state in which they are produced, they collide with values and worldviews adhered to by many nation-states. In this respect, Charlie Hebdo became a reference point for attacks on free speech in a number of other countries. Thus, the attack on a debate in Copenhagen where Lars Vilks was participating some weeks later was inevitably linked back to the events of Paris. Similarly, in May of the same year, disingenuous links were made between the mindlessly provocative art contest of drawings of the Prophet Muhammed held in Dallas, and the Charlie Hebdo cartoonists. In this respect, when we 
remember such events we are also partaking in a memory that is, to use Michael Rothberg's term, multidirectional. Charlie Hebdo is called to mind, now, when artistic expression comes under attack from Islamic fundamentalists. A group of understated cartoonists, familiar figures in France but otherwise little known until their death, have become unwitting global icons of the right to forms of freedom of expression that likely surpass what they themselves would have imagined to be acceptable.

Rothberg’s multidirectional memory refuses the ‘ownership’ of different pasts by different groups, instead it 'tries to draw attention to the dynamic transfers that take place between diverse places and times during the act of remembrance' (2009: 11). As the crowds gathered across the globe in the days following the Charlie Hebdo attacks, it was clear that, in this instance, the act of remembering brought many nations, languages, ethnicities, communities into a relationship of memory. This was emblematised by the group of leaders that marched arm in arm at the head of the 'marche républicaine’ of Sunday 11 January 2015, but was manifest, with greater spontaneity, in the gatherings of candle-bearing supporters televised from across the globe, and in the flurry of global emotion that in the early stages gripped social media outlets (before the backlash emerged some days later). The escalating field of influence in which Charlie Hebdo has come to operate post-factum have meant that the calls for national unity that characterised François Hollande’s immediate response seem in retrospect to have underestimated France's position as a focal point for international protest and commemoration - Charlie Hebdo suddenly 'belonged' to a far vaster population than that of France alone, given the global 'reaching out' that the attacks provoked. This multidirectionality has shapeshifted with each successive attack, when the lines of debate are reopened and Charlie Hebdo evoked in ever evolving frameworks of understanding. 
Inevitably, this ever-evolving construction of a memory narrative gives rise to alternative versions, sometimes subversive (for example Dieudonné’s controversial ‘je me sens Charlie Coulibaly'). ${ }^{1}$ Whilst an official, state-led memory narrative will frequently be one-directional, drawing on foundational moments in a national history to construct a framework within which to comprehend the event and form a united response, the explosion of Other memory narratives are multidirectional, drawing on a vast range of 'deterritorialized' influences to construct multiple narratives and frameworks which see the event through Other eyes. Hollande proclaimed hours after the attacks that 'Ces hommes, cette femme, sont morts pour l'idée qu'ils se faisaient de la France [...] Aujourd'hui c'est la République toute entière qui a été agressée. La République, c’est la liberté d'expression. La République, c'est la culture, c'est la création, c'est le pluralisme, c'est la démocratie’ (Hollande, 7 January 2015). In his role as Head of State he gave expression to the unifying and affirmative sentiments that it was his duty to pronounce, and that the people of France expected to hear. But his was only one, albeit powerful, voice in the emerging memory narrative, continually influenced by the 'rhizomatic networks of temporality and cultural reference that exceed attempts at territorialization (whether at the local or national level) and identitarian reduction' (Rothberg, 2010: 7).

\section{A one-directional memory}

As part of the state-led initiatives organised one year after the Charlie Hebdo attacks, three plaques were unveiled on 5 January 2016. On the site of the old Charlie Hebdo offices (new offices are now being used by the staff in an unspecified location on the periphery of Paris), 10 rue Nicolas-Appert, a plaque to the 11 victims killed there by the Kouachi brothers. On the boulevard Richard Lenoir, a plaque to Ahmed Merabet, the policeman killed during their escape. 
On the hypercacher supermarket at Porte de Vincennes, a plaque to the 4 victims killed by Coulibaly, two days later. And that same week at Montrouge, a plaque to Clarissa Jean-Philippe, the policewoman killed in Montrouge on January 8. The stupefying spelling error on the plaque at rue Nicolas Appert (Wolinski was spelt 'Wolinsky') distracted from the distinctive wording preceding the names: 'A la mémoire des victimes de l’attentat terroriste contre la liberté d'expression perpétrés dans les locaux de Charlie Hebdo le 7 janvier 2015'. The structure of the sentence places Charlie Hebdo towards the end - the attacks committed, we are led to understand, not against Charlie Hebdo and its cartoonists as such, but against a fundamental value of the French Republic - freedom of expression. The offices of Charlie Hebdo were merely the 'venue' for this act. This careful shift of focus away from the provocative drawings of the Prophet Muhammed and towards a moral value, the parameters of which are impossible to define, removes agency from the cartoonists themselves, drawing an affiliation between their journalistic activity and a problematic political vision - as though they were acting not as independent cartoonists, but somehow as purveyors of the state’s ‘vision'. Even more cynically perhaps, the wording seems to capitalise on the global outpouring of solidarity for France, making Tignous, Wolinski, Charb, Honoré and Cabu in particular into representatives of a

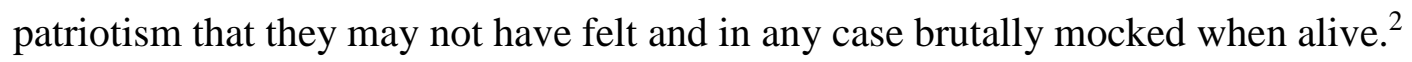

This appropriation of the attacks on the commemorative plaque was unveiled, ironically, on the same day that right-wing presidential contender Alain Juppé claimed 'je ne suis pas toujours Charlie', on discovering the anniversary edition with its cartoon of God as a runaway assassin (Bacqué, 2016). The cartoon favours laïcité, a founding principal of the Republic, but was clearly offensive to the Catholics, in particular, of France. It turned the Prophet Muhammed ‘joke’ back on a population that was so ready to defend it a year earlier. Some representatives of 
the Catholic Church took the offense better than others: in La Croix, Guillaume Coubert responded:

Tant mieux, cela donne à un quotidien catholique plus de liberté pour le commenter que si d'autres religions étaient explicitement en cause. Et on le commentera sans indignation. Par respect pour ceux qui sont morts, pour la douleur des survivants. Et parce que le refus de la violence est au cœur de notre foi. L’abbé Pierre-Hervé Grosjean l’a très bien dit hier sur son compte Twitter : 'De la crèche à la croix, notre Dieu se montre désarmé. Et se laisse caricaturer, sans cesser d'aimer.' (Coubert, 2016)

Info Chrétienne, meanwhile, was less open to becoming the butt of Charlie Hebdo's jokes: 'La Une tient Dieu pour responsable des tueries de ces attentats. Oui, cela laisse sans voix tant c'est désolant' (Anjou, 2016).

If Charlie Hebdo's commemorative issue shocked many, the state-led commemorations were on the other hand reassuringly predictable, though not without their own controversy. As part of these commemorations of the Charlie Hebdo attacks, a ceremony was held in the newly renovated and publicly appropriated memorial space of the Place de la République on 10 January 2016 to remember the victims of both January and November 2015. Wreaths were laid at the base of the statue of Marianne and a further plaque inaugurated alongside a memorial oak tree planted at the north end of the square. The ceremony was poorly attended, ironically largely due to the lengthy security measures - long queues of people waited to have their bags searched whilst the commemoration was already underway. Johnny Hallyday, a tax exile satirised tirelessly by Charlie Hebdo, sang Un dimanche de janvier, the song written by Jeanne Cherhal 
following the republican march. ${ }^{3}$ Victor Hugo was quoted, and the army sang La Marseillaise. The formality and contrived 'Frenchness' of the event contrasted dramatically with the polyphonic outburst of grief of 11 January 2015. Few were moved, as noted by Clément Sénéchal for Libération:

Triste spectacle, le 10 janvier place de la République, pour la commémoration des attentats de Charlie Hebdo. Tout semblait triste, mais d'une tristesse noircie, d'un vide écœurant, comme si un décorum chargé d'ombres et de gestes fantoches s'était laborieusement déplié sous la pluie. Une suite de maladresses symboliques qui confinent au navrant. L'enterrement définitif des passions joyeuses qu'il faudrait pourtant renouer pour faire face, ensemble, aux lacunes de notre société par où s’infiltre peu à peu une horreur sans dignité ni direction. (21 January 2016)

The official uniforms, the formal lines of politicians, the stiff choreography of the state-led act of remembrance - all hermetically sealed by the strict security structures that closed off the square to many of the public who had hoped to attend - stood in stark contrast to the everyday popular memorial of Place de la République (discussed below). If the commemorative gestures of the state enact the necessary duty of a government towards the nation's grief-stricken citizens, they also entrench the memory narrative within a discourse of patriotism that denies its global multidirectionality as well as its constant porosity.

\section{Place de la République}


Public acts of remembrance of Charlie Hebdo, however, have embraced and reflected memory's porous character. The focal point for this public remembering has been Place de la République, chosen spontaneously on the day of the attacks, long before official plaques had been commissioned and trees planted. A collective understanding drew Parisians to Marianne to light candles, wave pens, and comfort one another. Since 7 January 2015, in addition to its multifunctionality as a traffic roundabout, a place of commerce, a skate park, a campsite for the homeless, a meeting point... Place de la République has become a shrine, a constantly changing site of memory that draws visitors and mourners daily to read messages and often to place their own. This would not have been possible, had the architectural conditions not been created for the space to be used flexibly, and for the public to appropriate it. Prior to 2013, the Place de la République (known to Parisians as 'la Répu', meaning 'replete', or 'stuffed' and hinting to its disorder of noise and messy urbanism), was dominated by traffic, difficult to pass through or cross over, and few would have considered it a space conducive to reflection and grieving. It has long been, nonetheless, a space of political demonstration and the focal point of many a 'manif'. In this sense, the space was not adapted to the symbolic values afforded it by generations of French citizens.

In 2010 architects Pierre-Alain Trévelo and Antoine Viger-Kohler won a competition to reconstruct the Place de la République. Bearing in mind the difficulty faced by pedestrians, blocked in every direction by traffic, of reaching Morice's statue, the architects aimed to enable visitors, passers-by, demonstrators, the homeless - all end-users of the site - to 's'asseoir sur les genoux de la République’ with ease (Trévelo and Voger-Kohler, 2010). In doing so, they aimed to reunite the everyday citizen with the symbolic values supposedly represented by their nation- 
state. Indeed, the image that they describe hints towards seeking comfort and solace, though the architects could never have anticipated how the public would in the end come to use the space.

As Sibylle Vincendon wrote for Libération in 2010, their bold objective was to give a place to 'le vide' in central Paris:

Se dégage alors un grand espace au nord, à peu près les deux tiers de la superficie. Le défi du lieu. Pour la première fois dans son histoire, la place de la République va offrir un vide aux citoyens. A eux de trouver les usages pour l’occuper. Autour de la statue, l'espace sera minéral, vaste, et à même d'accueillir les rassemblements, petits ou grands. Sur les schémas, les architectes ont dessiné un marché. Plus au nord, sous les arbres, des terrasses de café avec leur édicule. Mais ce pourrait être une fête foraine, une foire à ceci ou cela... 'Cette place, dit Antoine Viger-Kohler, doit être réceptive à tous les usages.' 'Dans le cahier des charges, ajoute son comparse Trévelo, il était évident qu’il fallait conserver la capacité à manifester.' (Vincendon, 2010)

The architects hoped that the Place de la République would be an open space, the 'vide minéral' that they created allowing a public usage that was not preordained. Their fabrication of a mobile, porous, undefined space contrasts with the name of the site, with the pompous statue that is its focal point, in which the symbolism of the French nation is combined. It seems to acknowledge Michel de Certeau's following description of the city:

The city becomes the dominant theme in political legends, but it is no longer a field of programmed and regulated operations. Beneath the discourses that ideologize the city, the ruses and combinations of powers that have no readable identity proliferate; without 
points where one can take hold of them, without rational transparency, they are impossible to administer. (1984: 95)

Though the architects did not imagine that the newly opened site would become a shrine to victims of terror, their open structure created the conditions in which this was possible: the 'vide minéral' is conducive to gathering, to reflection, to meandering, to standing still, to prayer, to comforting one another, to standing back and taking photographs - even (strangely) smiling selfies. It also creates the sense of freedom necessary for so many people to inscribe their own messages of support on the statue, in multiple languages, in many colours, in pictures and in words. The absence of urban 'furniture' creates a space of ceremony, where not only the informal ceremonial gatherings of remembrance could take place, but also the official anniversary event, in all its static formality. Finally, but crucially, the open space was well adapted to the significant encampment of multiple media outlets from across the world in the days and weeks that followed the attacks. As they surrounded the statue of Marianne, closing off the noise and bustle of the surrounding city, their projections of memory images into people's homes across the world catalysed the creation of 'multidirectional encounters' (Rothberg, 2010: 9) with the event and the emerging memory narrative. This 'breaking news' footage of the evolving memorial at Marianne's feet contributed to the transnational becoming of a memory narrative 'freed from the (never actually) homogeneous space-time of the nation-state' (Rothberg, 2010:12).

\section{Rue Nicolas-Appert}


The focal point for remembering Charlie Hebdo is not, then, at the site that the attacks took place. The symbolism of the Place de la République but also its architecture, led to its role as a site of memory. What, then of the Rue Nicolas-Appert where the Charlie Hebdo offices used to be located? Tucked away between the Boulevard Beaumarchais and the Boulevard Richard Lenoir in the 11th arrondissement of Paris, rue Nicolas-Appert is a narrow side street with little traffic and, apart from the Comédie Bastille theatre, little of note - most buildings appear residential. This nondescript location was deliberately chosen for the Charlie Hebdo offices, since the magazine and its staff had been subject to death threats for some time prior to the attack. The offices were housed in a modern building of no particular distinction. Nothing on the building's facade gave away the location of Charlie Hebdo magazine therein. Indeed, those working for other companies housed in the same building were not necessarily aware that the shared the space with Charlie Hebdo, until the day of the attacks. That is not to say that the magazine staff were 'hiding' - their address was printed on their weekly magazine. Regrettably. The unmarked, unknown, undistinguished space of Rue Nicolas-Appert became in a matter of hours the centre of the world's attention. The dull, beige, modern building that was home to Charlie Hebdo's staff became the collection point for countless messages, tributes, candles, flowers. The Mairie de Paris regularly removed dead flowers and tidied the overspilling memory gestures into ever-neater spaces, until gradually, and particularly due to the multiplicity of attack sites post 13 November, République has become the favoured site of memory.

The rue Nicolas-Appert is, however, no longer an unmarked or undistinguished space. In the spirit of its deceased inhabitants, multiple works of street art have begun to cover the walls of their office building, both on the façade that faces onto rue Nicolas-Appert, and the façades looking onto the rue Gaby Sylvia and the Allée Verte. In a city where the viewing of works of art 
is traditionally via an array of grand art museums, the increasing prevalence and popularity of street art has come to question the traditionally structured and institutionalised encounter with artistic expression. The prevalence of street art on and around the site of the Charlie Hebdo attacks reunites the cartoonists with the marginal - prior to January 2015, they were only selling around 30,000 copies of the paper, and with a relatively 'niche' target audience. Moreover, the controversy they provoked and the subversive nature of their work ensured their marginal position. Street art, in its flirtation with vandalism, is equally marginal, exisiting as it does at the limits of the legal. As such it is often encountered as a provocation (though of course widely accepted today as an important form of contemporary art). This provocative character once again brings the viewer closer to the spirit of Charlie Hebdo, prior to its appropriation by the guardians of free speech.

On the rue Nicolas-Appert itself, black, sketched images of Charb and Cabu are set into the wall alongside the defiant quotation from Charb in 2012:

Je n'ai pas peur des represailles, je n'ai pas de gosses, pas de femme, pas de voiture, pas de crédit. C’est peut-être un peu pompeux ce que je vais dire, mais je préfère mourir debout que vivre à genoux (Charbonnier, 2012)

The quotation appears in an interview in Le Monde, published in September 2012, and then republished on the day of the attacks (Ternisien, 2012; 2015). Though these were not the words of Charb, they were originally spoken by Dolores Ibárruri, or La Pasionaria, the Spanish Communist leader. The quotation is accompanied by the 'Je suis Charlie' hashtag, and so encourages viewers to engage with the artwork via social media (no doubt creating for many the 
myth that Charb himself was author of those words). This simple addition plays with the locatedness of the artwork: it is inscribed onto the office walls of Charlie Hebdo, but it is shared across the globe. The interaction between commemorative street art and social media is crucial to the creation of multidirectionality in remembering Charlie Hebdo. The art is both carefully and precisely situated, and completely deterritorialised.

The rue Gaby Sylvia, perpendicular to rue Nicolas-Appert and little more than an alleyway, is now the exhibition space for a new mosaic work by Jérôme Gulon, or his alias 'Morèje'. A recognised contemporary mosaic artist, Morèje is one of very few to combine mosaic with street art. If most works of street art involve painting, stenciling, spraying or sketching onto the wall itself, a mosaic has the specificity of changing the character of a building façade with attached tiles altering the texture of an otherwise flat wall. This gives the mosaic a haptic appeal, as well as its visual draw, encouraging the 'viewer' to make physical contact with the work, to touch the city walls. His project, 'parcours', aims to reveal the hidden stories of city spaces through the chance encounter between a passer-by and the mosaics: 'Que le spectateur les découvre au hasard d'une promenade, sur un mur, à un coin de rue, ou à même le sol, ou qu'il suive le parcours proposé, elles agissent comme révélateur des éléments environnants’ (Morèje). In this respect, it references the physical practice of freerunning, or 'parkour', in which the practitioner uses their body to navigate the city in new ways. In 2011, Morèje placed mosaics of key figures of the 1871 Commune in a series of locations across Paris. In 2015, he installed mosaics of Cabu, Honoré, Tignous, Wolinski and Charb along the rue Gaby Sylvia. The mosaic tiles are multicoloured, and act as frames to softly sketched portraits of the cartoonists, accompanied by small cartoon insets. The mosaics are visible from the busy Boulevard Beaumarchais, so if the urban stroller glances up, sees the mosaics, and follows the parcours 
down rue Gaby Sylvia, he or she will reach the rue Nicolas-Appert. In this sense, Morèje tries to tempt city-dwellers from their beaten path and guide them down the otherwise unremarkable alley to the site of the attack. The public are encouraged to become agents in the discovery and appropriation of city spaces, as their subjective experience of those spaces is altered.

Further works of street art exist all around the horseshoe road structure formed by rue Gaby Sylvia - rue Nicolas Appert - Allée Verte. Some are by known artists, others are anonymous. Along with the official plaque, they transform the mundane office building into a palimpsestial space of both memorial and exhibition. From the solid permanence of the engraved marble block expressing a national message of commemoration above one of the entrance doors, to the Banksy-esque stencils of the victims emerging around the street corner, the public encounter with the site of the attack is via a métissage of different styles and aesthetics that jolt the viewer by their unlikely proximity to one another. The spontaneity of the works, removed from the thoughtful curatorship of museum display rooms, distanced from the sanitizing barrier between viewer and viewed, and above all vulnerable to the public desire - whether to view, to appreciate, to efface, to alter, to copy, to touch, to photograph, are indicators of the openness of the memory process, its malleability, its constant rewriting.

Much has been commented upon regarding the handily tweetable slogans and logos that emerge now from 'terrorist' crimes and which, in some ways like the state narrative, attempt to fix memory, to package it for public use. While fascinating, this focus on the mass-produced memory statement of 'Je suis Charlie' occludes the heterogenous and constantly evolving public interaction with remembering Charlie Hebdo that is occurring on the pavements, the walls and the monuments of the city in which the magazine is produced, as well as via social meida. As Rothberg has demonstrated, a ‘direct line’ does not run ‘from memory to identity’ (2009: 5). 
This spontaneous engagement with the city, which has, it should be added, been largely supported by the Mairie de Paris, shares with the social media response its refusal to allow the memory to be 'owned' by a specific group. Its openness to all those who encounter and engage with it, whatever their political, ethnic, linguistic or religious background, is opposed to the attempt to entrench the narrative in French 'national identity' that typified official commemorative events. The rearticulations of Charlie Hebdo that continue to echo across the city prove at least one slogan maker right. Inscribed on a poster, rue Nicolas-Appert, 'Vous voulez tuer Charlie? Vous venez de le rendre immortel'.

\section{Notes}

1. On 11 January 2015, French comedian Dieudonné M'bala M'bala posted this message on Facebook. He was detained and subsequently fined 30,000 euros (Le Monde, 2015).

2. Worth reading on this matter are the comments of Tzvetan Todorov in Libération, notably his call for 'le refus d'adopter sans s'y attarder les interprétations fournies par les représentants du gouvernement ou par les grands médias' (Faure and Calvet, 1 January 2016).

3. Hallyday made the front cover of Charlie Hebdo frequently. In December 2006 he was depicted on the cover alongside the caption 'Voleur comme un Francais, con comme un Belge, chiant comme un Suisse' (no. 757, 20 December 2006)

\section{Bibliography}

9/11 Memorial Museum. Help Build the Collection. Available at: https://www.911memorial.org/help-build-collection (accessed 15 March 2016) 
Anjou G (2016) Pour Charlie Hebdo, Dieu est un assassin en fuite. La réponse d’Info Chrétienne. Info Chrétienne (5 January). Available at: https://www.infochretienne.com/selon-charliehebdo-dieu-serait-un-assassin-la-reponse-dinfo-chretienne/ (accessed 18 March 2016).

Baudrillard J (2002) L’Esprit du terrorisme. Paris, Galilée.

Bacqué R (2016) Le Nouveau public de Charlie est-il prêt pour l'humour de Charlie. Le Monde, 6 January. Available at: http://www.lemonde.fr/police-justice/article/2016/01/06/lenouveau-public-de-charlie-est-il-pret-pour-l-humour-de-charlie_4842337_1653578.html (accessed 19 March 2016).

Calvet C and Faure S (2016) Tzvetan Todorov: ‘Les Insoumis refusent de céder à l’adversaire, mais aussi à leurs propres démons’. Libération, 1 January. Available at: http://www.liberation.fr/debats/2016/01/01/tzvetan-todorov-les-insoumis-refusent-deceder-a-l-adversaire-mais-aussi-a-leurs-propres-demons_1423886 (accessed 21 March 2016).

Charlie Hebdo, 757, 20 December 2006.

Coubert G (2016) Charlie Hebdo: un dieu assassin? La Croix, 4 January. Available at: http://www.la-croix.com/Editos/Charlie-Hebdo-un-dieu-assassin-2016-01-04-1399648 (accessed 18 March 2016)

De Certeau M (1984) The Practice of Everyday Life, trans. Steven Rendall. Berkeley: Universi ty of California Press.

Hollande F (2015) Allocution à la suite de l'attentat au siège de Charlie Hebdo. Available at: http://www.elysee.fr/declarations/article/allocution-a-la-suite-de-l-attentat-au-siege-de-c harlie-hebdo/ (accessed 16 March 2016). 
Huyssen A (1995) Twilight Memories: Marking Time in a Culture of Amnesia. New York and London: Routledge.

Le Monde (2015) 'Je me sens Charlie Coulibaly’. 30,000 euros d’amende requis contre Die udonné. 4 February. Available at: http://www.lemonde.fr/societe/article/2015/02/04/jeme-sens-charlie-coulibaly-30-000-euros-d-amende-requis-contre-dieudon ne_4569791_3224.html (accessed 18 March 2016).

Morèje. Parcours. Available at: www.moreje.fr (accessed 10 March 2016).

Oudin S (2015) Charlie Hebdo: le collectif 17, plus jamais. France Inter, 27 January. Available at: http://www.franceinter.fr/emission-grand-angle-charlie-hebdo-le-collectif-17-plusjamais (accessed 23 March 2016).

Rothberg M (2009) Multidirectional Memory: Remembering the Holocaust in the Age of Deco lonization. California: Stanford University Press.

Rothberg M (2010) Between Memory and Memory: From Lieux de Mémoire to Noeuds de Mémoire, Yale French Studies 118/119: 3-12.

Rothberg M, Sanyal D and Silverman M (2010) Editors’ Note: Noeuds de Mémoire. Multidirec tional Memory in Post-War French and Francophone Culture, Yale French Studies 118/119: 1-2.

Sénéchal C (2016) Les Commémoration des attentats de janvier ou l’ère du vide. Libération, 21 January. Available at: http://www.liberation.fr/france/2016/01/21/les-commemorationsdes-attentats-de-janvier-ou-l-ere-du-vide_1427921 (accessed 23 March 2016).

Ternissien X (2012; 2015) A Charlie Hebdo, on n’a 'pas l'impression d'égorger quelqu'un avec un feutre’. Le Monde, 20 September 2012; 7 January 2015. Available at: 
http://www.lemonde.fr/actualite-medias/article/2012/09/20/je-n-ai-pas-l-impression-degorger-quelqu-un-avec-un-feutre_1762748_3236.html (accessed 20 March 2016).

Tritah F (2015) Attentats de Paris: 1000 personnes recueillent autour de l'arbre de la liberté à Périgueux. France Bleue, 18 November. Available at: https://www.francebleu.fr/infos/faits-divers-justice/attentats-de-paris-1000-personnes-serecueillent-autour-de-l-arbre-de-la-liberte-1447805754 (accessed 25 March 2016).

Vincendon S (2016) La République, Place de la Concorde. Libération, 5 January. Available at: http://www.liberation.fr/france/2016/01/05/la-republique-place-de-la-concorde_1424523 (accessed 10 March 2016).

Vitkine A (2016) Attentats, au coeur du pouvoir. France 3, 3 January. 